\title{
Resurgence of human bothriocephalosis (Diphyllobothrium latum) in the subalpine lake region
}

\author{
Raffaele PEDUZZI ${ }^{1) *}$ and Renata BOUCHER-RODONI ${ }^{2)}$ \\ ${ }^{1)}$ Istituto Batteriosierologico Cantonale, Via G. Buffi 6, 6904 Lugano, Switzerland \\ ${ }^{2)}$ Biologie des Invertébrés marins (BIMM, MNHN), UPESA 8044 CNRS, 55 rue Buffon, 75005 Paris, France \\ *e-mail corresponding author: raffaele-peduzzi@ti.ch
}

\begin{abstract}
Human bothriocephalosis is once again being found in various catchment basins in the subalpine region, including Lago Maggiore and Lac Léman, which however are not isolated cases. Domestic animals are thought to be responsible for the survival of the parasite during the period when no human cases were reported. The new phenomenon of eating raw or poorly cooked fish is responsible for the resurgence of human bothriocephalosis, which affects various lake districts in Europe. This habit of eating raw fish might lead to the resurgence of a much more dangerous human parasitosis, transmitted in a similar way: infestation by Anisakis.
\end{abstract}

Key words: Bothriocephalosis, Diphyllobothrium, Subalpine region

\section{INTRODUCTION}

Water is a vehicle for many infectious and parasitic agents. Changes in social, cultural and agricultural habits have been accompanied by changes in the health risks associated with water. Human infection by $\mathrm{Di}$ phyllobothrium latum (Cestoda: Pseudophyllidaea), the broad tapeworm, is caused by the ingestion of raw or poorly cooked fish containing plerocercoid larvae. The infestation can occur only if the larvae are still alive after their ingestion. Maturation lasts for 5 to 6 weeks before egg production; the adult worm can be over 10 meters long and contains 2000-3000 proglottids. Diagnosis is usually based on the identification of characteristic eggs or proglottids in human faeces. The life cycle of the parasite includes two intermediate hosts (copepod and fish, Fig. 1). The occurrence of this parasite was originally restricted to the «old world», i.e. in lakes of various European countries such as Sweden, Finland, Russia, Poland, Rumania, Austria, Scotland, Ireland (O’Fel 1992; Dorucu et al. 1995; Byrne et al. 2000). Bothriocephalosis was apparently already present during pile-dwelling times: eggs have been found in human coprolites from Neolithic sites, in Jura (Bouchet 1997). Its introduction into the United States is recent. Cases have also been reported lately from Argentina and Chile (Semenas \& Ubeda 1997) and from Asiatic countries like Japan and Korea, where the consumption of raw fish is common (Chung et al. 1997).

It used to be thought that this parasitosis had disappeared from many European and American regions. However, this paper reports that Diphyllobothrium is still present in fish samples from Lago Maggiore and Lago d'Orta, and that human infestation has been increasing in recent years in the subalpine region.

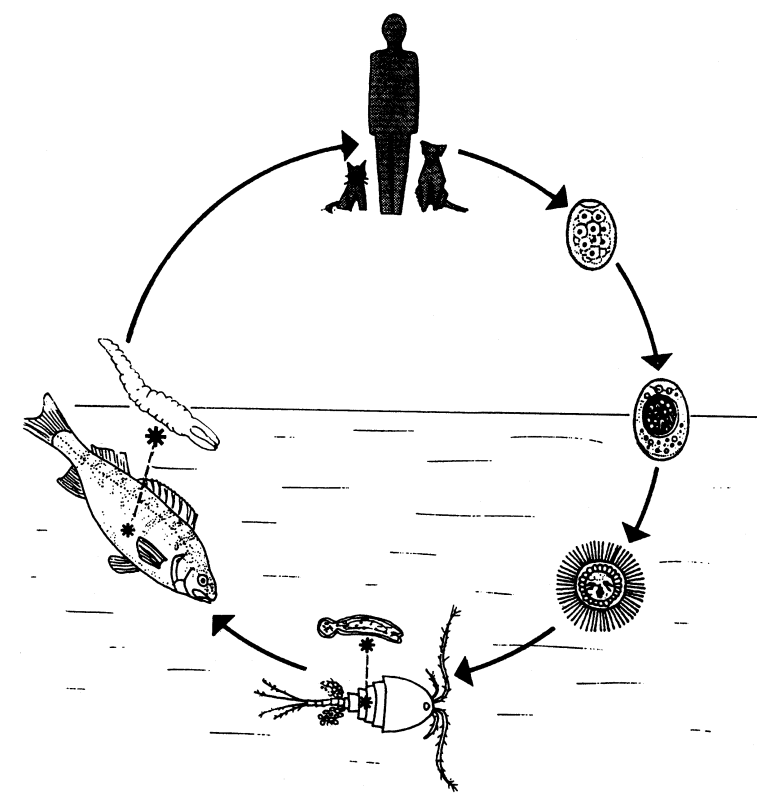

Fig. 1. Life cycle of Diphyllobothrium latum in Lago Maggiore. Two intermediate hosts are involved, a copepod Cyclops and a fish (mainly Perca fluviatilis but also Esox lucius and Lota lota). Plerocercoid larvae are found in fish muscle as well as in its body cavity.

\section{MATERIAL AND METHODS}

\subsection{Human faeces analyses}

Over 35,000 samples of human faeces were analysed in the last ten years, and tested for helminth infestation. To detect the presence of Diphyllobothrium, the samples were homogenised by a stomaker and by a diphasic technique derived from the Telemans-Rivas method (Bourée 1989). After centrifugation, Diphyllobothrium eggs were examined under a light microscope. 


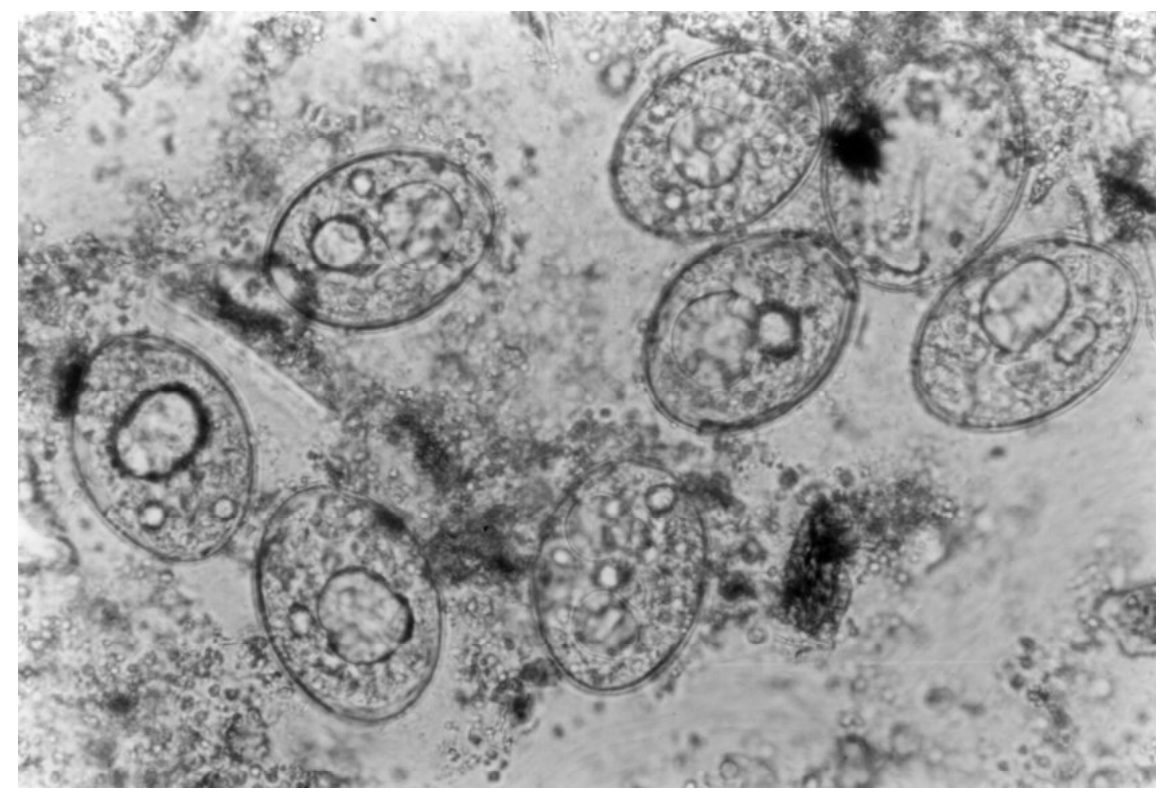

Fig. 2. Microscope view of

Diphyllobothrium latum eggs, showing the high density of their release, which can reach one million eggs a day. Size of a single egg: $50 \times 70 \mu \mathrm{m}$.

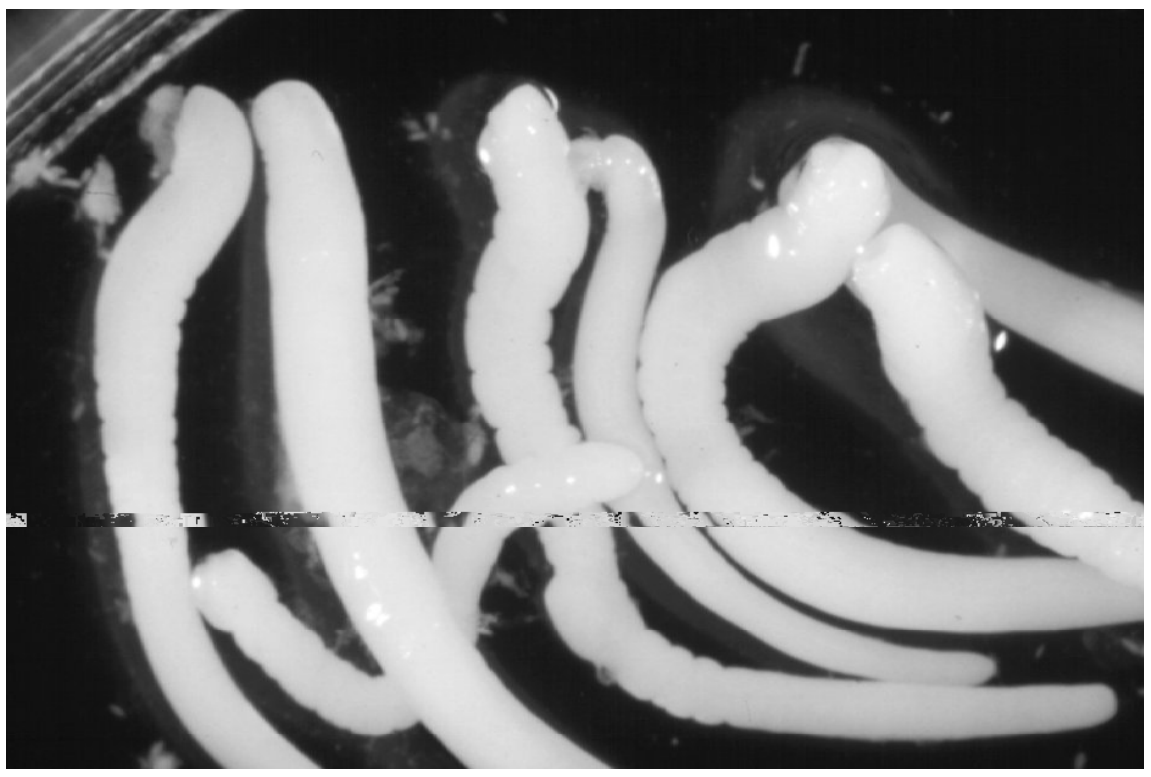

Fig. 3. Fish muscle (Perca fluviatilis) infestation by a large number of plerocercoid larvae of

Diphyllobothrium latum. Scale $8 \times$.

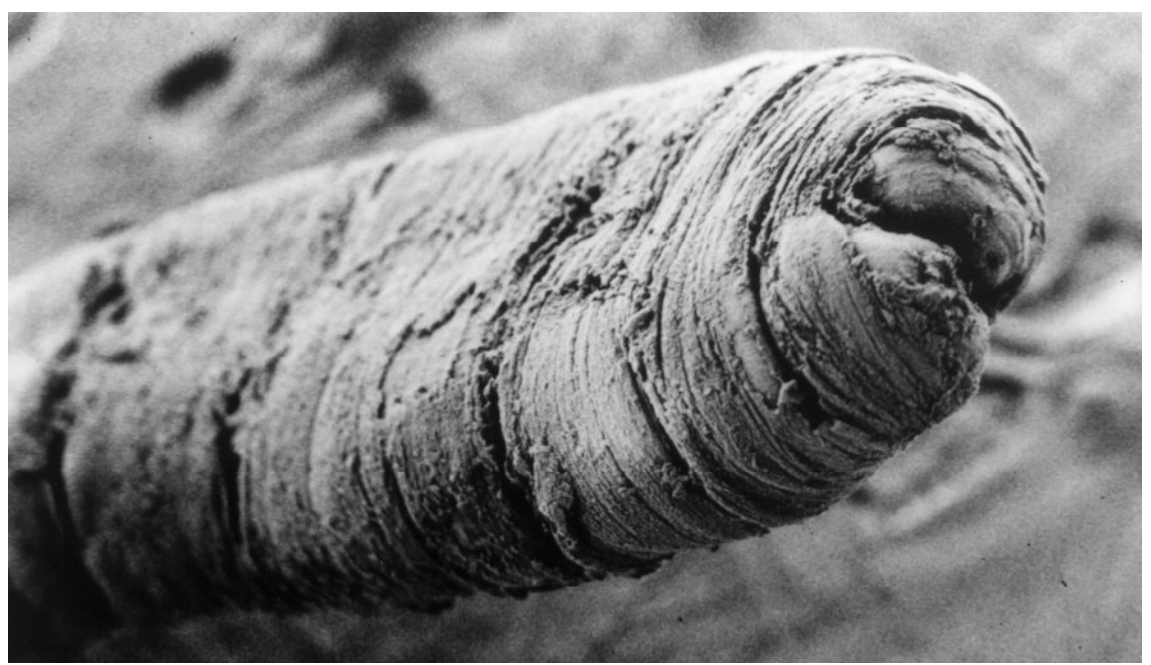

Fig. 4. Scanning electron microscope view of a plerocercoid larva of Diphyllobothrium latum: detail of buccal apparatus. Scale $45 \times$. 


\subsection{Fish examination}

Muscle samples of Perca fluviatilis were collected in various lakes from the subalpine region along the SwissItalian border (Tab. 1), and tested for the presence of parasite larvae by anatomic and microscopic observation.

Tab. 1. Presence of Diphyllobothrium latum larvae in the muscles of perch (Perca fluviatilis) from five Italian and Swiss-Italian subalpine lakes. I = Italy; $\mathrm{CH}=$ Switzerland.

\begin{tabular}{lccc}
\hline Lake & $\mathrm{N}^{\circ}$ fish & $\begin{array}{c}\mathrm{N}^{\circ} \text { D.latum } \\
\text { larvae }\end{array}$ & \% infec. \\
\hline Lugano (I-CH) & 107 & 0 & 0 \\
Varese (I) & 35 & 0 & 0 \\
Mergozzo (I) & 50 & 0 & 0 \\
Maggiore (I-CH) & 309 & 24 & 7.8 \\
Orta (I) & 15 & 5 & 33.3 \\
\hline
\end{tabular}

\subsection{Electron microscope analyses}

The samples were dehydrated in a series of ethanol baths of increasing concentration (20 to $100 \%, 10 \mathrm{~min}$. per bath) followed by a last bath in pure acetone, before being transferred to the $\mathrm{CO}_{2}$ critical point dryer CPD030 (Balzers). Gold shadowing was performed in a sputter coater SDC-050 (Balzers), before observation with a scanning electron microscope (ISI SS40).

Tab. 2. Species and frequency of helminth isolated from human faeces from 1982 to 1999 , out of 37,800 analyses.

\begin{tabular}{lc}
\hline Species & Number of cases \\
\hline Trichuris trichiura & 138 \\
Taenia sp. & 127 \\
Enterobius vermicularis & 66 \\
Ascaris lumbricoides & 44 \\
Diphyllobothrium latum & 31 \\
Ancylostoma sp. & 31 \\
Hymenolepis sp. & 12 \\
Strongyloides stercoralis & 9 \\
Dicrocoelium sp. & 8 \\
Schistosoma haematobium (urine) & 5 \\
Trichostrongylus sp. & 1 \\
Clonorchis sinensis & 1 \\
Total number of cases & 476 \\
\hline
\end{tabular}

\section{RESULTS AND DISCUSSION}

In the Swiss-Italian subalpine region, considered in this study, Diphyllobothrium latum infestation in man had been presumed extinct since 1970 . However, a first new case was identified from human faeces in 1983, and since then 31 other cases have been reported in the local population (anamnesis excludes infection from other sources), indicating that the parasitosis is now in prog??ress (Peduzzi 1990; Fig. 2). At present, in the geographical area considered, infestation by Diphyllobothrium is the most frequent in man after
Taenia, Trichuris and Ascaris (Peduzzi \& De Rossa 1999; Tab. 2). The percentage of Diphyllobothrium eggs varied from 0.3 to $0.4 \%$ of all the samples analysed in this study, a much higher value than the $0.01 \%$ frequency reported for this parasite by the $\mathrm{CDC}$, Atlanta, on the basis of epidemiological data relating to USA (Stürchler 1986).

Tab. 3. Presence of Diphyllobothrium latum larvae in the muscles of perch (Perca fluviatilis) from Lago Maggiore. I = Italy ; $\mathrm{CH}=$ Switzerland.

\begin{tabular}{|c|c|c|c|}
\hline Fishing zones & $\mathrm{N}^{\circ}$ samples & $\mathrm{N}^{\circ}$ D.l. larvae & $\%$ infec. \\
\hline Riva Piana-Muralto $(\mathrm{CH})$ & 29 & 4 & 13.8 \\
\hline Bolle Magadino $(\mathrm{CH})$ & 15 & 1 & 6.7 \\
\hline San Nazzaro $(\mathrm{CH})$ & 11 & 0 & 0.0 \\
\hline Ranzo $(\mathrm{CH})$ & 12 & 0 & 0.0 \\
\hline Foce Ticino Verzasca $(\mathrm{CH})$ & 22 & 3 & 13.6 \\
\hline Vira Gambarogno (CH) & 28 & 3 & 10.7 \\
\hline Laveno (I) & 80 & 5 & 6.2 \\
\hline Angera (I) & 50 & 1 & 2.0 \\
\hline Arona (I) & 15 & 2 & 13.3 \\
\hline Stresa (I) & 15 & 3 & 20.0 \\
\hline Baveno (I) & 16 & 0 & 0.0 \\
\hline Verbania (I) & 16 & 2 & 12.5 \\
\hline TOTAL & 309 & 24 & 7.8 \\
\hline
\end{tabular}

As far as fish infestation is concerned, plerocercoid larvae are found in fish muscle (Figs 3 and 4). A high infestation rate is recorded in perch (Perca fluviatilis) from many fishing areas of Lago Maggiore (Bonini et al. 1998; Tab. 3); the infestation is also in progress in other subalpine lakes, such as the Franco-Swiss lac Léman (Peduzzi et al. 1994). However, the resurgence of human bothriocephalosis is not restricted to these two major lakes, but involves most of the catchment basins in the entire subalpine region (Tab. 4). In addition, Golay \& Mariaux (1995) reported 73 cases of bothriocephalosis from various areas in Switzerland, including the Léman region (Geneva, Vaud), but also Neuchâtel, Fribourg and Bern.

Tab. 4. Cases of human bothriocephalosis reported from various laboratories (19901995). I=Italy; $\mathrm{CH}=$ Switzerland; $\mathrm{F}=$ France.

\begin{tabular}{lc}
\hline Lake & Number of cases \\
\hline L. Léman (F-CH) & 24 \\
L. Maggiore (I-CH) & 28 \\
L. Como (I) & 1 \\
L. Iseo (I) & 8 \\
L. Garda (I) & 12 \\
\hline
\end{tabular}

These results show that the parasite cycle was still active even when the disease did not appear in humans. Man is not the only ultimate host, so that the cycle may have been maintained through domestic animals (mainly cats and dogs). Human beings used to be protected by the habit of cooking fish at high temperatures, since the 
most effective means of killing the parasite is by heating or freezing (Tab. 5).

Tab. 5. Survival of plerocercoid larvae to freezing and heating.

\begin{tabular}{lc}
\hline Temperature & Survival time \\
\hline$-10^{\circ} \mathrm{C}$ & $1-7$ days \\
$+4{ }^{\circ} \mathrm{C}$ & 72 hours \\
$+50^{\circ} \mathrm{C}$ & 10 min. \\
\hline
\end{tabular}

Changes in eating habits, i.e. the consumption of raw or poorly cooked fish, popularised by specialised restaurants, have caused infestation in humans to reappear in areas where it was considered extinct. This alerts us to the risk of another infection, in which the process of contamination is similar but which is much more dangerous : infestation by Anisakis. In any case, eating raw or poorly cooked fish from lakes or sea can increase the risk of food-transmitted dangerous parasitosis in man.

\section{REFERENCES}

Bonini, P., S. Montorfani, R. Peduzzi \& P. Renon. 1998. Situazione della plerocercosi nei laghi insubrici italo-svizzeri. Valutazione del potenziale zoonosico. Obiettivi \& Documenti Veterinari, Bologna, 4: 65-72.

Borroni, I. \& E. Grimaldi. 1974. Ecologia dell'infestione da larve plerocercoidi di Diphyllobothrium latum (Cestoda: Pseudophyllidaea) a carico delle specie ittiche recettive del Lago Maggiore. Riv. Parassitol., 35(4): 261-276.

Bouchet, F. 1997. Helminth eggs : trace elements of neolithic and paleolithic parasitosis on French sites. C.R. Séances Soc. Biol. Fil., 191(4) : 529-536 (in French).

Received: January 2000

Accepted: March 2001
Bourée, P. 1989. Dictionnaire de parasitologie. Editions Ellipses, Paris: $126 \mathrm{pp}$.

Byrne, C.J., C. Grey, C. Holland \& R. Polle. 2000. Parasite community similarity between four Irish lakes. $J$. Helminthol., 74(4): 301-305.

Chung, P.R., W.M. Sohn, Y. Jung, S.H. Pai \& M.S. Nam. 1997. Five human cases of Diphyllobothrium latum infection through eating raw flesh of redlip mullet, Liza haemotocheila. Korean J. Parasitol., 35(4): 283-289 (in Korean).

Dorucu, M., D.W. Crompton, F.A. Huntingford \& D.E. Walters. 1995. The ecology of endoparasitic helminth infections of brown trout (Salmo trutta) and rainbow trout (Oncorhynchus mykiss) in Scotland. Folia Parasitol. (Praha), 42(1): 29-35.

Golay, M. \& J. Mariaux. 1995. Situation de Diphyllobothrium latum L. 1758 (Cestoda: Pseudophyllidea) dans quatre lacs du plateau suisse. Bull. Soc. Neuch. Sci. Nat., 118: 79-86.

O'Fel, A. 1992. Parasitologie et mycologie. La Madeleine Editions C. et R.: 369 pp.

Peduzzi, R. 1990. Résurgence de la botriocephalose (parasitose à Diphyllobothrium latum) dans la région du Lac Majeur. Signalement de 18 cas chez l'homme. Médecine \& Maladies Inf., Paris, 20(10): 493-497.

Peduzzi, R., A. Demarta \& M. Tonolla. 1994. Problèmes hygiéniques des lacs subalpins: influences des stations d'épuration et réapparition du Diphyllobothrium latum. In: ACTES Quatrième conférence Internationale des Limnologues d'Expression Française, Marrakech.

Peduzzi, R. \& R. De Rossa. 1999. I parassiti più frequenti nella pratica analitica quotidiana. Tribuna Medica Ticinese, 573-576.

Semenas, L. \& C. Ubeda. 1997. Human diphyllobothriasis in Patagonia, Argentina. Rev. Salude Publica, 31(3): 302-307 (in Spanish).

Stürchler, D. 1986. Intestinale Parasitosen. Schweizerische Medizinische Wochenschrift., 116: 804-810. 